Журнал«Герспективита інновації наукиљ

(Серія«Гедагогіка», Серія«ГЕихологія», Серія«Медицина»

№4(4) 2021

УДК 373.5 (477.6)

https://doi.org/10.52058/2786-4952 -2021-4(4)-86-95

Босва Тетяна Іванівна кандидат історичних наук, доцент, Університет сучасних знань, вул. Велика Васильківська, 57/3, м. Київ, 03150, тел.: (044) 28752-90, e-mail: aleksandr.58pochta@gmail.com, https://orcid.org/0000-0002-0521-4580

\title{
РОЗВИТОК ГІМНАЗІЙНОЇ ОСВІТИ НА ДОНЕЧЧИНІ (ДРУГА ПОЛОВИНА ХІХ - НА ПОЧАТКУ ХХ СТ.)
}

Анотація. У статті висвітлюється проблема розвитку гімназійної освіти на Донеччині у другій половині XIX - на початку XX ст. У цей період на усіх державних рівнях відбувалися значні зміни: економічні, політичні, культурні та освітні. Становлення гімназійної освіти відбувалося в умовах промислового розвитку країни. Соціальне замовлення вимагало перегляду діючої концепції гімназійної освіти. Урядова освітня політика на рубежі XIX-XX ст. в цілому мала суперечливий характер: йшло постійне протиборство двох політико-освітніх парадигм - консервативної й ліберальної,. Незважаючи на це, цей історичний період характеризувався послідовним розвитком середньої освіти: відбувалась модернізація чоловічої класичної й реальної освіти; сформувалась потужна система жіночої середньої освіти; почала активно розвиватися середня комерційна освіта. У зазначений дослідженням час на Донеччині діяли як чоловічі так і жіночі гімназії $\mathrm{y}$ цілому гімназійна освіта на Донеччині почала формуватися 3 70-х років XIX ст. і була більш методично забезпечена в порівнянні з початковою. Незважаючи на необхідну плату, бажаючих вступити до них було занадто, проте їх мережа не задовольняла потреби населення. Треба відзначити ряд педагогічних умов, що впливали на розвиток гімназій: існування великої кількості типів шкіл, відсутність наступності та послідовності в ланках системи освіти, існування різних дидактичних концепцій, недостатне фінансування. Автор підкреслює, що названа тема потребує подальшого дослідження.

Ключові слова: Донеччина, гімназійна освіта, чоловічі гімназії, жіночі гімназії, розвиток, суперечливий характер.

Boieva Tetiana Ivanivna Candidate of Historical Sciences, Associate Professor, University of Modern Knowledge, vul. Velyka Vasylkivska, 57/3, Kyiv, 03150, tel.: (044) 287-52-90, e-mail: aleksandr.58pochta@ gmail.com, https://orcid.org/0000-0002-0521-4580 


\title{
THE DEVELOPMENT OF GYMNASIUM EDUCATION IN DONETSK REGION ( SECOND HALF OF XIX - BEGINNING XX CENTURIES)
}

\begin{abstract}
This article gives a review of the development of gymnasium education in Donetsk reqion in the second half XIX - beginning XX centuries. During this period, significant changes took place at all levels of government: economic, political, cultural and educational. The formation of gymnasium education took place in the conditions of industrial development of the country. The social order required a revision of the current concept of gymnasium education. The government educational policy at the turn of the XIX-XX centuries in general was contradictory. There was a constant confrontation of two political and educational paradigms - conservative and liberal. However, this historical period was characterized by the consistent development of secondary education. There was a modernization of men's classical and real education. There was formed a powerful system of women's secondary education. During this period there were men's and women's gymnasiums. The gymnasium education in Donetsk region began to form in the 70's of the XIX century. It was more methodically developed than primary education. In gymnasiums it was necessary to pay, but many people wanted to study there. Gymnasiums did not meet the needs of the population of Donetsk region. There were a number of pedagogical conditions that influenced the development of gymnasiums: the existence of a large number of types of schools, lack of continuity and consistency in the education system, the existence of various didactic concepts, insufficient funding. The author notes that this problem need in the next investigation.
\end{abstract}

Keywords: Donetsk region, gymnasium education, men's gymnasiums, women's gymnasiums, development, contradictory character.

Постановка проблеми. Тема статті зумовлена підвищенням ролі освіти в якісному оновленні всіх ланок господарського механізму й соціальної інфраструктури сучасної України. Для найбільш повного осмислення історичних процесів, шляхів подальшого розвитку країни сьогодні, як ніколи, гостро постає питання всебічного вивчення історії України, зокрема історії культури та історії освіти як її невід'ємної складової. В умовах розвитку незалежної України аналіз і акумуляція історичного досвіду в ділянці розвитку освіти має як суто наукове, так і прикладне, практичне значення.

Аналіз останніх досліджень і публікацій. Загалом проблема розвитку гімназійної освіти на Донеччині у 1961- 1917 рр. досліджувалася з точки зору загальної освітянської політики уряду. Прокопенко С.Л. зробив дослідження розвитку гімназійної освіти на Катеринославщині [1]. Він з'ясував, що як результат реформи середньої освіти 1849-1852 рр. та кінця 50-х - першої половини 60-х рр. змінилися контрреформою 1871-1872 рр., спробою другої контрреформи у 1880-х pp., а 3 кінця XIX ст. і до 1917 р. - пошуком підходів до чергового реформування середньої освіти, які так і не увінчалися успіхом. 
Журнал«Герспективитаінновації науки»

(Серія«Гедагогіка», Серія«Гцихологія», Серія«Медицинв»

№4(4) 2021

Аналіз автора показав, характерною прикметою часу було створення різноманітних громадських організацій, які опікувалися розвитком освіти. Значних масштабів досягла благодійність у сфері освіти представників місцевої еліти та ділових кіл. Автор цієї праці не ставив перед собою мету дослідити розвтиок середньої освіти на Донеччині. Тому ця тема потребує продовження дослідження.

Про складний період формування мережі навчальних закладів на Донеччині післяреформенної доби дають уяву роботи В.І.Подова i В.С.Курило [18], O.I.Мармазової [19], І.В.Довжука [20] та ін.

Вони робили спроби досліджувати положення стосовно освітніх закладів, що були прийняти у досліджуваний час, їх праці показують освітянську політику взагалі в Наддніпрянській Україні. Дослідники торкалися деяких аспектів названої теми, епізодично в контексті тих чи інших проблем більш масштабного плану. Названі автори не ставили завдання комплексного дослідження розвитку гімназійної освіти у регіоні в окреслений період,

Мета статті. Питання розвитку освіти в Україні, зокрема на Донеччині, 3 позицій сучасної науки почали вивчатися лише в останні роки, при цьому все ще зберігається певна фрагментарність цих досліджень та багато архівних матеріалів ще не побачили світ. Цим і зумовлюється мета статті, що висвітлює гімназійну освіту в Донбасі у досліджуємий період.

Виклад основного матеріалу. Урядова освітня політика на рубежі XIX-XX ст. в цілому мала суперечливий характер: йшло постійне протиборство двох політико-освітніх парадигм - консервативної й ліберальної,. Незважаючи на це, цей історичний період характеризувався послідовним розвитком середньої освіти: відбувалась модернізація чоловічої класичної й реальної освіти, оновлювався іiі зміст; сформувалась потужна система жіночої середньої освіти; почала активно розвиватися середня комерційна освіта [1, 197-198].

Важливе значення для розвитку середньої освіти мала ліквідація в ході реформи школи кінця 1850-х - першої половини 1860-х рр. монополії держави на освіту, надання права засновувати навчальні заклади земствам і міським думам, станам, товариствам і приватним особам.

У цілому середні навчальні заклади поділялися на чоловічі та жіночі [4, с. 17]:

- чоловічі: гімназії з терміном навчання 8 років, реальні училища 3 терміном навчання 7 років, комерційні училища з терміном навчання $7-8$ років;

- жіночі: гімназії з терміном навчання 7 - 8 років, деякі з них включали 4річні прогімназії, єпархіальні училища, інститут благородних дівиць;

- середню духовну освіту давали духовні училища 3 4-річним терміном навчання і духовна семінарія з 4 - 6-річним терміном навчання.

Гімназії розподілялися на повні (семикласні) та неповні (чотирикласні) прогімназії. У свою чергу вони поділялися на два типи: класичні та реальні. Перші ставили своєю метою давати загальну класичну освіту й готувати учнів до 
вступу в університет, другі - практичні знання і можливість подальшого навчання у вищих спеціальних навчальних закладах. Напередодні реформ, за архівними даними, середніх навчальних закладів у Старобільському повіті Харківської губернії не існувало [5, арк. 19]. У Катеринославській губернії перші середні навчальні заклади відкрилися ще в 1839 р. згідно з Положенням про навчальні заклади Луганського гірничого округу. Це - Луганське заводське й Лисичанське гірниче училища [6, с. 79]. Їх завдання - підготовка учнів до занять технічних, креслярських, писемних, госпітальних тощо, тобто, підготовка спеціалістів середнього класу для потреб гірничозаводської промисловості. Кожне 3 них розраховувалося на 24 казенні учні. В училища приймалися найкращі випускники початкових гірничих шкіл, що існували в селищах Луганська (у Кам’яному Броді, Лисичанську й Верхньому (Третій Роті)).

Названі училища відіграли важливу роль у підготовці робітників для гірничозаводської промисловості, яка почала швидко розвиватися. Проіснували вони більше двох десятків років. Після скасування кріпацтва, мешканці Кам'яного Броду та Третьої Роти були повернені до колишнього стану казенних селян, а Луганський ливарний завод прийшов у занепад, тому названі середні навчальні заклади були закриті в 60-ті рр. XIX ст.

До 60-х рр. ХІХ ст. жіноча середня освіта практично була відсутня, за винятком інститутів благородних дівиць імператриці Марії. Ці освітні заклади не відігравали значної роли у зв'язку з малочисельністю, до них приймалися лише діти дворян та духовенства. 3 початком реформ громадськість звертає особливу увагу на жіночу середню освіту. Положення про гімназії та прогімназії 1864 р. i 1874 р. відкрили доступ до них широких прошарків населення імперії. За опублікованими статистичними даними в 1873 p. в Російській імперії налічувалося 55 жіночих гімназій і 116 прогімназій. У наступні 20 років їх чисельність зростає втричі, що свідчить про успіх цих жіночих навчальних закладів та про зацікавленість у них населення [7, с. 118-119].

Відкриватися знову середні освітні заклади на Донеччині почали в $70-80-\mathrm{x}$ роках XIX ст., коли суспільство вимагало спеціалістів для потреб вищої освіти. За архівними даними, у м. Маріуполі в серпні 1875 р. відкрили одразу 2 прогімназії - чоловічу й жіночу. На базі цих прогімназій 1 липня 1876 р. за наказом імператора Олександра II була утворена Маріупольська гімназія у складі 1 підготовчого і 4 нижчих класів. Потім щорічно відкривали по одному класу до повного складу. У 1907 р. тут вже існувало 16 класів: 1 підготовчий, 8 основних i 7 паралельних. У квітні 1876 р. відкрита Маріїнська жіноча гімназія [8, арк. 2-4].

Гімназії та реальні училища відкрилися також у містах Бахмуті, Луганську, Старобільську, Слов’янську, Лисичанську. Жіноча казенна гімназія, при якій були організовані вечірні загальноосвітні курси за програмою чоловічої гімназії та дві приватні жіночі прогімназії, діяли також у Юзівці, яка на той час стала значним центром середньої освіти [9, арк. 26]. У 1917 р. тут нараховувалося 4 середні навчальні заклади: восьмикласне комерційне училище, міська жіноча 
Журнал«Герспективита інновації науки

(Серія «Гедагогіка», Серія «Гтихологія», Серія «Медицина»

№4(4) 2021

гімназія, єврейська приватна чоловіча гімназія Гофнера, приватна жіноча гімназія Гаргера. У комерційному училищі навчалося 599 учнів, у міській жіночій гімназії - 180 учениць, у єврейській приватній гімназії Гофнера - 120 юнаків [10].

9 вересня 1869 р. відкрилася Бахмутська чоловіча гімназія, котра знаходилась у відомстві Міністерства народної освіти. Але спочатку заснували шестикласну прогімназію, а 1 липня 1879 р. вона перетворена у восьмикласну гімназію. У 1904 р. губернське земство асигнувало кошти на будівництво нового приміщення для вихованців гімназії, що свідчить про тяжке фінансове положення Міністерства народної освіти [11, арк. 341].

У кінці 1908 р. тут діяло 8 основних, один підготовчий і один паралельний класи. Гімназія мала власний будинок і фінансувалася казною. На 15 грудня 1908 p. у гімназії працювало 23 викладачі, навчалося 328 учнів. Крім того, у Бахмуті діяло дві жіночі гімназії. Першу жіночу гімназію в Бахмуті, котра носила ім'я Ї̈ї Імператорської Високості Великої княжни Марії Павлівни, відкрили ще в 1884 p. у складі 4-х класів. У 1896 р. iї перетворили у восьмикласну. Гімназі Гімназія мала власний будинок. Витрати коштів на ії утримання щорічно складали 26585 руб. 50 коп. Бахмутська жіноча гімназія № 2 відкрилася 4 вересня 1906 р. у складі 4-х класів. У 1908 - 1909 рр. відкрився 5-й клас, у 1909 -1910 н. р. - 6-й, у 1910 - 1911 н. р. - 7-й клас. Гімназія мала 7 основних класів, підготовчий і 4 паралельні при 1, 2, 3 і 6-му класах. Усього тут навчалося 493 учениці [12, с. 75].

Приватні гімназії почали відкривати з розвитком промисловості та в умовах нових соціально-економічних відносин. У Маріупольському повіті 1 жовтня 1905 р. у повітовому центрі відкрилася жіноча гімназія В.С.Остословської у складі чотирьох основних класів і підготовчого з двома відділеннями й 388 учнями. У 1910 p. у місті Лисичанську діяла приватна прогімназія Е.С.Семенової, у місті Бахмуті Імператора Миколи Олександровича гімназія С.Садчікова. У червні 1906 р. дочка священика М.М.Левицька відкрила приватну жіночу прогімназію, пізніше їй надали статус Юзівської міської жіночої гімназії 3 повними правами державних гімназій. Це був елітний навчальний заклад. Плата за навчання складала від 140 до 300 руб. на рік.

Приватна гімназія Р.М.Воскресенської (з 1916 р. - К.К.Локтюшової) відкрита після 1908 р. у місті Луганську. Приватна гімназія К.П.Чвалинської імені Ї̈̈ Імператорської Високості Великої княжни Марії Павлівни почала діяти у м. Луганську 11 квітня 1911 р. у складі 4-х основних класів, пізніше перетворена на п’ятикласну. У Юзівці на той же час працювали 3 приватні гімназії $\mathrm{i}$ комерційне училище.

У Маріуполі діяла чоловіча гімназія Лобачевського, у Луганську - жіноча гімназія і професійна школа Цимбалової та Виноградової [13, арк. 1]. У 1917 р. у Лисичанську була відкрита гімназія товариства „Просвіта”. 31910 р. діяла Миколаївська жіноча гімназія у Старобільську. 
Навчання у гімназіях було платним, тому навчалися в них діти заможних сімей. Проте потяг до знань широких верств народу переважав і деякі навчальні заклади приймали дітей селян та міщан без плати за навчання. Це, на наш погляд, безперечно позитивні зрушення у становій освітній політиці царського уряду на початку XX ст. Зауважимо, що в другій половині XIX ст. дітей селян, прислуги тощо серед учнів середньої школи було мало. Тільки події революції 1905 - 1907 pp. та громадсько-педагогічний рух змусили імперський уряд піти на такі заходи.

Протоколи педагогічних рад, циркулярні листи директорів, журнали класів, заяви батьків, атестати випускників, спогади вихованців гімназій, що зберігаються в державних архівах, дають змогу відтворити діяльність цих навчальних закладів.

Директори гімназій були високоосвіченими педагогами. Так, Катерина Петрівна Чвалинська (уродженая Голуб), 1868 року народження, родова дворянка, освіту й виховання отримала в Петербурзькому училищі Ордена Святої Катерини. У 1911 р. призначена начальницею заснованої нею гімназії, яка стала однією з найкращих приватних жіночих гімназій Луганська. Випускниця цієї гімназії Варвара Степанівна Дубиніна (у дівоцтві Воронкова) пам'ятає свою начальницю як взірець жіночої чарівності, доброти та вихованості. У грудні 1914 р. К.П.Чвалинську нагородили золотою медаллю з надписом „За усердие”, яку носили на грудях на Анненській стрічці [14].

У 1916 р. приватну гімназію Р.М.Воскресенської прийняла Катерина Костянтинівна Локтюшова, яка одержала освіту в Бердянській жіночій гімназії. Окрім керівництва вона викладала арифметику, іiі попередня начальниця Р.М.Воскресенська викладала німецьку мову. Важливим завданням власників гімназій був контроль за благодійністю учнів згідно з положенням Комітету Міністрів від 26 травня 1867 р. 3 архівних документів відомо, що 30 березня 1913 p. за участь у недозволеному зборі 9 січня 1912 р. в жіночій гімназії Витлюр звільнені учениці без дозволу вступити до будь-якого навчального закладу Міністерства народної освіти. Про що повідомлялися усі казенні та приватні гімназії [15, арк. 23].

Навчатися в гімназії бажало багато мешканців регіону, рівень освіти був високий. Про це свідчать архівні анкетні дані вчителів, програми гімназій, оцінки випускників тощо. 3 протоколів засідань педагогічних рад приватної жіночої гімназії Р.М.Воскресенської відомо, що в 1892 р. у 5 класі успішність становила: з Закону Божого - 100\%, з російської мови - 100\%, з алгебри - 89\%, з геометрії89\%, з історії - 94,5\%, з малювання -100\%. Загальна успішність становила $77 \%$. Поведінка надто відмінна [16, арк. 35].

У жіночих гімназіях Луганська вчилися дочки міщан, цехових, селян, менш - духовенства, купців, родових дворян. При більш глибокому вивченні документів, уявлення про доступність навчальних закладів на початку XX ст. лише дітям багатих або заможних батьків не підтверджується. У документах того часу графа „стан” залишалася не заповненою. Окрім того, плата стала більш 
Журнал«Герспективитаінновації науки»

(Серія«Гедагогіка», Серія«Гцихологія», Серія«Медицинв»

№4(4) 2021

доступною. Так, у гімназії К.П.Чвалинської вона становила в молодшому відділенні гімназії у 1915 - 1916 навчальному році 50 руб., виростаючи від класу до класу. Максимальна плата була 120 руб. на рік. Згідно $з$ документами Російської громади машинобудівних заводів Гартмана, середній заробіток по заводах за 1914 р. становив 537 руб. 41 коп. на рік. Отже, прості люди мали змогу платити за навчання своїх дітей у середніх навчальних закладах.

Педагогічний колектив гімназій приймав заходи по підвищенню грамотності учнів. До того треба відзначити, що здібні учні з селян вчилися не гірше дітей заможних станів. Архівні документи свідчать, що учениця IV класу Луганської жіночої гімназії К.К.Локтюшової Богданова Фекла Василівна отримала такі оцінки: Закон Божий - відмінно, російська мова - відмінно, математика відмінно, географія - відмінно, малювання - відмінно, рукоділля - відмінно, гімнастика - добре [17, арк. 5].

Навчальний рік починався 315 серпня і тривав до 15 травня. Навчалися дівчата від 7-18 років. В гімназіях діяли підготовчий клас, сім основних класів $i$ восьмий - додатковий. Усі дисципліни, що викладалися в гімназіях, поділялися на обов'язкові та необов'язкові. До обов'язкових відносили: російську мову й арифметику (по 23 години на тиждень), Закон Божий (14 годин), історію (12 годин), географію i природознавство (по 10 годин), рукоділля (9 годин) i чистописання (6 годин). Навчання велося тільки російською мовою, українську мову у гімназіях не вивчали.

Обов’язковим для вивчення був курс рукоділля, де дівчата навчалися шити, в’язати, вишивати. Р.М.Воскресенська вважала, що іiі вихованки мають знати також домоводство. Про необхідність уведення цієї дисципліни до навчального плану гімназії вона подала пропозицію до Міністерства народної освіти [16, арк. 5]. I 31912 р. в жіночих середніх навчальних закладах упроваджується курс домоводства, який включав: кулінарне мистецтво (приготування страв, заготівка i збереження провізії, головні прийоми визначення якості харчових продуктів), догляд за білизною і одягом (починка, прання, прасування, чистка, збереження), догляд за приміщенням (опалення приміщення, виведення пилу, бруду). Архівні дані свідчать, що обов'язковим для гімназисток було носити форму, яка в різних гімназіях відрізнялася кольором: у казенній гімназії учениці носили зелену, у гімназії Локтюшової - коричневу, у Чвалинської - синю.

Патріотичне виховання також вважалося необхідним для гімназисток. Звісно, це робилося у великодержавному російському дусі. У 1913 р. в державі широко святкувався ювілей 300-ліття дома Романових. Ретельно до нього готувалося й Міністерство народної освіти. Усі навчальні заклади одержали декілька розпоряджень щодо купівлі брошур, книг, альбомів, портретів імператорської сім’ї.

Випускниці четвертого й сьомого класів одержували свідоцтва й атестат про закінчення відповідно початкової або середньої школи. Бажаючі одержати професійну педагогічну освіту могли продовжити навчання у восьмому 
допоміжному класі, після закінчення якого вони отримували звання домашньої вчительки або наставниці (але лише в тих випадках, якщо їх нагороджували золотою або срібною медаллю). За правилами гімназій випускниці мали обміняти атестат про закінчення курсу на свідоцтво, що видавалося в канцелярії Попечителя навчального округу. Для цього необхідно було подати: а) прохання на ім'я Попечителя навчального округу; б) атестат про освіту; в) свідоцтво про закінчення допоміжного VIII класу; г) метричне свідоцтво; д) 12 руб. для оформлення свідоцтва. Домашні вчительки за правилами повинні кожен рік складати звіт про свою роботу та подавати його відповідному директору училища. Таким чином, одержуючи атестат, випускниці гімназій здобували i професію. Атестат також давав можливість вступу до вищих навчальних закладів.

Висновок. Отже, освіту в жіночих гімназіях вихованки отримували належну. Педагогічний колектив мав високий на той час рівень освіти. Матеріальна база була достатньою. Незважаючи на необхідну плату, бажаючих вступити до гімназій було занадто, а мережа жіночих гімназій в регіоні була недостатньою.

Поряд 3 жіночими на Донеччині розвивались і чоловічі гімназії та реальні училища. 1 липня 1914 р. циркуляр Міністерства народної освіти затвердив навчальний план чоловічої класичної гімназії (з восьмирічним курсом навчання i підготовчим відділенням): Закон Божий, російська, церковнослов'янська, латинська, грецька мови, філософська пропедевтика, законознавство, математика, фізика, історія, географія, німецька й французька мови, природознавство, малювання, чистописання.

У зазначений дослідженням час на Донеччині діяли такі чоловічі гімназії: Бахмутська, Луганська, Старобільська. Катерино-Олександрівська чоловіча казенна гімназія у Бахмуті заснована 1 липня 1898 р. у складі 4-х основних класів, у 1901 р. ï перетворили на шестикласну, а з початку 1903 / 1904 н.р. - у повну гімназію.

Поряд 3 класичними гімназіями, де більше уваги приділялося вивченню давніх мов (латинської та грецької), існували середні навчальні заклади, де в основу програми були покладені точні та природознавчі науки. За архівними даними, у 1908 р. в Катеринославській губернії нараховувалося 15 міських училищ. Такі навчальні заклади існували в містах Бахмуті, Луганську, Маріуполі й Слов'янську.

У цілому гімназійна освіта на Донеччині почала формуватися 3 70-х років XIX ст. і була більш методично забезпечена в порівнянні 3 початковою. Незважаючи на необхідну плату, бажаючих вступити до них було занадто, проте їх мережа не задовольняла потреби населення.

\section{Лimepamypa:}

1. Прокопенко С.Л. Середня освіта на Катеринославщині другої половини XIX-початку XX ст. Дис... канд. іст. наук: 07.00.01 -Дніпро, 2019.- 292 с. 
Журнал«Герспектвиитаіноовації наукиљ

(Серія«Гедагогіка», Серія«Гтихологія», Серія«Медицинв»

№4(4) 2021

2. Друганова О. М. Розвиток приватної ініціативи в освіті України (кінець XVIII початок XX століття) : автореф. дис. на здобуття наук. ступеня д-ра пед. наук: 13.00.01. Харків,2009. 42 с.

3. Гаєвська Л.А. Державно-громадське управління загальною середньою освітою в Україні (друга половина XIX - початок XX ст.) Умань, 2008. 332 с.

4. Боєва T.I. Розвиток мережі середньої освіти в Донбасі в кінці XIX - на початку XX ст. // Історичні записки. Збірник наукових праць. Вип.2. - 2004. - С.16 - 22.

5. Про земські навчальні заклади і про стипендіатів земства. 19.07.-5.05.1871 р. - Оп. 243 - Спр. $151-36$ арк.

6. Курило В.С., Подов В.И. Образование в Донбассе (XIX - начало XX вв.). - Луганск: ЛГПУ, 1999. - $114 \mathrm{c.}$

7. Днепров Э.Д. Школа в России во второй пол. XIX в. // Советская педагогика. - 1975. - №9. - С.118- 126 .

8. Витяг з протоколів засідань Маріупольської міської думи, доповідь Маріупольської міської управи зборам Маріупольської міської думи та переписка 3 попечителем Одеського навчального округу, попечительною радою Маріупольської жіночої гімназії про відкриття в м. Маріуполі жіночої гімназії, 1876 р. - Оп.1 - Спр.16 - 24 арк.

9. Звіт депутатів навчального округу про іспити в приватних навчальних закладах у Катеринославській губернії. 16.06.1910-02.09.1910 - Оп.35 - Спр.1380 - 162 арк.

10. Задніпровська Л.Д. Юзівська приватна жіноча гімназія // Педагогічна скарбниця Донеччини. - 1996. - №1. - С.61 - 62.

11. Доклади губернської земської управи Катеринославському губернському і земському зборам (копії) про навчально-виховну роботу, про асигнування коштів на будівництво житлових і дорожніх споруд, про збори податків з селян та з інших питань. 1904 р. - Оп.1 Спр.447 а. -400 арк.

12. Отчет Бахмутской уездной земской управы за 1911 г. - Екатеринослав, 1912. - 215 с.

13. Свідоцтва та атестати про освіту, метричні свідоцтва учнів Луганської жіночої гімназії. - Оп. 1 - Спр. 2 - 108 арк.

14. Кто учил наших бабушек? / Наша газета. - 1996. - Август (84).

15. Циркуляр міністерства народної освіти про збір грошей для потреб імперіалістичної війни 1914 р. Список діячів приватної середньої школи комітету Всеросійської ліги, переписка 3 інспектором народних училищ з питання навчання. - Оп. 1 - Спр.7 - 45 арк.

16. Переписка з директором та інспектором народних училищ 3 питання роботи гімназії. - Оп.1 - Спр.11 - 61 арк.

17. Свідоцтва про закінчення гімназії. - Оп. 1 - Спр.1 - 82 арк.

18. Курило В.С., Подов В.И. Образование в Донбассе. (XIX - начало ХХ вв.). - Луганск: ЛГПУ, 1999. - $114 \mathrm{c}$.

19. Мармазова О.I. Просвітницька діяльність земств в Україні (кінець XIX - початок XX ст.) Автореф. дис.... д-ра пед. наук. Харків, 2002. - 33с.

20. Довжук І.В. Промисловий розвиток Донбасу в системі економіки Наддніпрянської України (кінець XIX-початок XX): Монографія. Луганськ: вид-во СНУ ім.В.Даля, 2003. - 312 с.

\section{References:}

1. Prokopenko, S.L. (2019). Serednja osvita na Katerinoslavshhini drugoï polovini HIHpochatku HH st. [Secondary education in the Ekaterinoslav region of the second half of the XIX-early XX century]. Candidate's thesis. Dnipro: Dnipro [in Ukrainian].

2. Druganova, O. M. (2009). Rozvitok privatnoï iniciativi v osviti Ukraïni (kinec' XVIII pochatok XX stolittja) [Development of private initiative in education of Ukraine (late XVIII - early XX century)]. Doctor's thesis. Harkiv: Harkiv [in Ukrainian]. 
3. Ga€vs'ka, L.A. (2008). Derzhavno-gromads'ke upravlinnja zagal'noju seredn'oju osvitoju v Ukraïni (druga polovina HIH - pochatok HH st.) [State and public administration of general secondary education in Ukraine (second half of the XIX - beginning of the XX century)]. Uman', [in Ukrainian].

4. Bo€va, T.I. (2004). Rozvitok merezhi seredn'oï osviti v Donbasi v kinci HIX - na pochatku HH st. [Development of the network of secondary education in Donbass in the late XIX - early XX centuries]. Istorichni zapiski - Historical notes, 2, 16 - 22 [in Ukrainian].

5. Pro zems'ki navchal'ni zakladi i pro stipendiativ zemstva [About zemstvo educational institutions and about zemstvo scholarship holders]. 19.07.-5.05.1871 r. - Op. 243 - Spr.151 - 36 ark [in Ukrainian].

6. Kurilo, V.S., Podov, V.I. (1999). Obrazovanie v Donbasse (HIH - nachalo HH vv.) [Education in Donbass (XIX - early XX centuries)]. Lugansk: LGPU [in Russian].

7. Dneprov, Je.D. (1975). Shkola v Rossii vo vtoroj pol. HIH v. [School in Russia in the second century XIX century]. Sovetskaja pedagogika - Soviet pedagogy, 9, 118 - 126 [in Russian].

8. Vitjag z protokoliv zasidan' Mariupol's'koï mis'koï dumi, dopovid' Mariupol's'koï mis'koï upravi zboram Mariupol's'koï mis'koï dumi ta perepiska z popechitelem Odes'kogo navchal'nogo okrugu, popechitel'noju radoju Mariupol's'koï zhinochoï gimnaziï pro vidkrittja v m. Mariupoli zhinochoï gimnaziï, 1876 r. - Op.1 - Spr.16 - 24 ark. [in Ukrainian].

9. Zvit deputativ navchal'nogo okrugu pro ispiti $\mathrm{v}$ privatnih navchal'nih zakladah $\mathrm{u}$ Katerinoslavs'kij guberniï. 16.06.1910-02.09.1910 - Op.35 - Spr.1380 - 162 ark. [in Ukrainian].

10. Zadniprovs'ka, L.D. (1996). Juzivs'ka privatna zhinocha gimnazija [Private Women's Gymnasium]. Pedagogichna skarbnicja Donechchini - Pedagogical Treasury of Donetsk Region, 1, $61-62$ [in Ukrainian].

11. Dokladi guberns'koï zems'koï upravi Katerinoslavs'komu guberns'komu i zems'komu zboram (kopii) pro navchal'no-vihovnu robotu, pro asignuvannja koshtiv na budivnictvo zhitlovih i dorozhnih sporud, pro zbori podatkiv z seljan ta z inshih pitan'. 1904 r. - Op.1 - Spr.447 a. - 400 ark. [in Ukrainian].

12. Otchet Bahmutskoj uezdnoj zemskoj upravy za 1911 g. - Ekaterinoslav, 1912. - $215 \mathrm{~s}$.

13. Svidoctva ta atestati pro osvitu, metrichni svidoctva uchniv Lugans'koï zhinochoï gimnaziï. - Op. 1 - Spr. 2 - 108 ark. [in Ukrainian].

14. Kto uchil nashih babushek? / Nasha gazeta. - 1996. - Avgust (84).

15. Cirkuljar ministerstva narodnoï osviti pro zbir groshej dlja potreb imperialistichnoï vijni 1914 r. Spisok dijachiv privatnoï seredn'oï shkoli komitetu Vserosijs'koï ligi, perepiska z inspektorom narodnih uchilishh $z$ pitannja navchannja [Circular of the Ministry of Public Education on the collection of money for the needs of the imperialist war of 1914. List of private high school figures of the All-Russian League Committee, correspondence with the inspector of public schools on the issue of education]. - Op.1 - Spr.7 - 45 ark. [in Ukrainian].

16. Perepiska $z$ direktorom ta inspektorom narodnih uchilishh $z$ pitannja roboti gimnazii [Correspondence with the director and inspector of public schools on the work of the gymnasium]. Op. 1 - Spr.11 - 61 ark. [in Ukrainian].

17. Svidoctva pro zakinchennja gimnaziï [Certificates of completion of the gymnasium]. Op. 1 - Spr. 1 - 82 ark. [in Ukrainian].

18. Kurilo, V.S., Podov, V.I. (1999). Obrazovanie v Donbasse. (HIH - nachalo HH vv.) [Education in Donbass. (XIX - early XX centuries.)]. Lugansk: LGPU [in Russian].

19. Marmazova, O.I. (2002), Prosvitnic'ka dijal'nist' zemstv v Ukrä̈ni (kinec' XIX - pochatok $X X$ st.) [Educational activity of zemstvos in Ukraine (end of XIX - beginning of XX century)]. Extended abstract of Doctor's thesis. Harkiv: Harkiv [in Ukrainian].

20. Dovzhuk, I.V. (2013). Promislovij rozvitok Donbasu v sistemi ekonomiki Naddniprjans'koï Ukraïni (kinec' XIX $\square$ pochatok XX) [Industrial development of Donbass in the economic system of Dnieper Ukraine (late XIX $\square$ early XX)]. Lugans'k: vid-vo SNU im.V.Dalja [in Ukrainian]. 